\title{
Effect of the halothane genotype on intramuscular fat deposition in swine
}

\author{
L.R. Alves, R.C. Antunes, R.B. Andrade, A.A. Storti, S.L.B. Reis, \\ L.G. Carrazza, C.F. Osava and N.V. Costa \\ Faculdade de Medicina Veterinária, Universidade Federal de Uberlândia, \\ Uberlândia, MG, Brasil \\ Corresponding author: R.C. Antunes \\ E-mail: robson@famev.ufu.br
}

Genet. Mol. Res. 13 (1): 363-370 (2014)

Received August 9, 2013

Accepted October 28, 2013

Published January 21, 2014

DOI http://dx.doi.org/10.4238/2014.January.21.4

\begin{abstract}
Intramuscular fat (IMF) content has been identified as an important factor in determining the quality of pork. Previous studies have suggested that IMF deposition may be associated with the presence of the halothane (HAL) gene. This study aimed to evaluate the effect of the HAL gene on IMF deposition in crossbred pigs of commercial lines, which were killed at a slaughterhouse under official inspection. The genotype of the HAL gene was determined by polymerase chain reaction-restriction fragment length polymorphism analysis. IMF was analyzed from longissimus dorsi samples. Among all animals analyzed, $42.36 \%$ were of the HalNN genotype and $57.64 \%$ were of the HalNn genotype. The average IMF content of all samples was $2.14 \%$. Variation in IMF between genotypes was evaluated by analysis of variance. No significant difference in IMF deposition, which could be based on the presence of the halothane allele, was observed, at least in heterozygotes.
\end{abstract}

Key words: IMF; Heterozygous; Meat quality; HAL 


\section{INTRODUCTION}

Domestic swine producers have recently placed major emphasis on genetic improvement programs, focusing mainly on the selection of swine carcasses with high amounts of lean meat. This selection has been important in order to meet consumer demand for products that are low in animal fat, due to the known correlation between animal fat and cardiovascular disease (Terra and Fries, 2000).

Changes in genetic and/or environmental factors can determine the speed and extent of post mortem biochemical reactions in pigs, which results in a lower quality meat known as pale, soft and exudative (PSE). PSE meat is a serious problem for the pork industry because it is characterized by low water retention, paleness, excessive loss of exudate, extreme flaccidness, weight loss, lower productivity, and poor consumer acceptability (Rübensam, 2000). PSE meat results from a rapid decrease in $\mathrm{pH}$ within $24 \mathrm{~h}$ after slaughter, and has been linked to the presence of the halothane (HAL) gene in animals. According to Fujii et al. (1991), this gene maps to chromosome 6 and represents a mutation that disrupts the structure of the ryanodine (RYR1) protein, which is part of the calcium channel of the sarcoplasmic reticulum. The mutation in this protein results in a deficiency in calcium regulation, causing an increase in its release after animal bleeding (Sarcinelli et al., 2007).

The HAL gene has pleiotropic effects on susceptibility to stress, which is associated with carcass meat content and quality, and the homozygous recessive genotype (Halnn) is associated with PSE meat (Swatland, 1982; Sather et al., 1991; Geers et al., 1994). Despite this association, the HAL gene has been exploited to stimulate an increase in carcass meat content. Crossing terminal heterozygous males (HalNn) with free homozygous females that do not have the recessive allele (Halnn) produces 50\% HalNn and 50\% HalNN progeny, with a resulting increase of 1 to $2 \%$ in the meat content of the carcasses, presumably without affecting its quality (Fávero and Bellaver, 2007). However, according to Bastos et al. (2001), the HAL gene is associated with a decrease in meat quality, even in heterozygotes (HalNn).

Another characteristic frequently considered by pork consumers is the amount of fat in the product. Consumer concerns about health, especially cholesterol levels, have led swine farmers to use various scientific techniques, e.g., investing in cross-breeding and other breed improvement strategies, to reduce the percentage of fat in the meat (Roppa, 1999). Roppa (1999) also revealed that 70 to $72 \%$ of pork fat is concentrated beneath the skin of the back fat. Only 22 to $24 \%$ of the carcass fat lies between muscles, whereas the 2 to $4 \%$ of fat contained within muscles, known as intramuscular fat (IMF), is responsible for the flavor, juiciness, and tenderness of the meat.

IMF content has been identified as an important factor in determining pork quality, and recently, genes with important effects related to this feature have been identified (Plastow, 2000). Dekkers (2004) showed that heart fatty acid-binding protein (FABP3) and adipocyte fatty acid-binding protein (FABP4) genes influence the deposition of IMF with limited impact on bacon thickness. These genes can therefore be selected for to increase IMF content, thus improving the flavor and tenderness of the meat without increasing bacon thickness (Veerkamp et al., 2000). However, studies conducted by Kukoyi et al. (1981) and Tam et al. (1998) verified that IMF deposition might also be related to the presence of the HAL gene.

Therefore, the present study aimed to evaluate the effect of the HAL gene on the deposition of IMF in commercial crossbred swine slaughtered in a cold storage slaughterhouse under official inspection. 


\section{MATERIAL AND METHODS}

\section{Sample collection}

In March 2009, 144 pigs of approximately 150 days of age that were bred at commercial farms were selected for inclusion in the study. The animals belonged to two different commercial lineages: 72 were from the cross-breeding A line (male-carrier boars - Nn: Pietran and Duroc x female: Large White and Pietran, lacking the HAL gene - NN) and 72 were from the cross-breeding B line (male-carrier boars: Pietran pure $\mathrm{x}$ female: Large White and Pietran, lacking the HAL gene - NN), with 36 castrated males and 36 females in each group.

Before being sent to slaughter, the pigs were tattooed with identification numbers on both shoulders and both hind legs. Blood samples $(5 \mathrm{~mL})$ were collected from the marginal ear vein of these animals and were stored in properly labeled vials containing anticoagulant solution (citrate).

The samples were carried in a Styrofoam box containing recyclable ice packs for material cooling and preservation. Then, the samples were frozen at $-20^{\circ} \mathrm{C}$ for subsequent extractions of genomic DNA.

The animals were transported in adapted trucks to a cold storage plant, where they were slaughtered according to RIISPOA protocols (Brazil, 1952). After unloading, the pigs were housed in pigpens for $12 \mathrm{~h}$ with no access to food but with access to water. Later, they were driven to the slaughter room, passing through sprinkler showers, and were stunned using the electrical method at two points, with an average voltage of $350 \mathrm{~V}$ and average amperage of 0.85 A. Following slaughter, bleeding, scalding, toilet, evisceration, and inspection operations were carried out. The animals were stored in chilled chambers at a temperature of $0.5^{\circ}-2^{\circ} \mathrm{C}$ immediately after slaughter.

At $24 \mathrm{~h}$ after slaughter, meat samples were removed from the loin muscle (longissimus dorsi) for IMF analysis. The samples were obtained from the right side of half-carcasses of each animal.

\section{DNA analysis and extraction}

DNA analysis was performed in the Laboratory of Molecular Genetics, Federal University of Uberlândia (LAGEM/UFU). Genetic material was extracted from blood leukocytes by adapting the protocol for DNA extraction and quantification described by Antunes (1997).

DNA was amplified using the polymerase chain reaction-restriction fragment length polymorphism (PCR-RFLP) technique (Saiki et al., 1985, 1988) with the following specific primers: F-5'-GTGCTGGATGTCCTGTGTTCCCT-3' and R-5'-CTGGTGACATAGTTGAT GAGGTTTG-3' (Brenig and Brem, 1992). The procedure was carried out in a final volume of $30 \mu \mathrm{L}$, containing approximately $100 \mathrm{ng}$ DNA sample, $1 \mathrm{mM} \mathrm{MgCl}_{2}, 6 \mathrm{pmol}$ of each primer, $50 \mu \mathrm{M}$ dNTPs, 1.25 IU Taq DNA polymerase (Fermentas ${ }^{\circledR}$ ), and corresponding buffer solutions. The reaction was carried out in a thermal cycler over 35 cycles of $94^{\circ} \mathrm{C}$ for $30 \mathrm{~s}$ for denaturation, $58^{\circ} \mathrm{C}$ for $30 \mathrm{~s}$ for primer annealing, and $72^{\circ} \mathrm{C}$ for $45 \mathrm{~s}$ for DNA extension.

After amplification, the DNA was cut by the restriction enzyme HhaI, submitted to $2.8 \%$ agarose gel electrophoresis, stained with ethidium bromide, and viewed under ultraviolet light (Sambrook et al., 1989). 
The genotype of each animal was determined according to the specific banding pattern. HalNN animals have a restriction site for the HhaI enzyme at both alleles, and thus produce 2 bands of 48 and 85 bp after enzyme restriction. In contrast, HalNn animals contain 1 allele with the mutation $1843(\mathrm{C} \rightarrow \mathrm{T})$, which eliminates the enzyme restriction site, leading to the production of a single intact band of $133 \mathrm{bp}$ in addition to 2 two bands mentioned above after enzyme restriction.

\section{Determination of IMF content}

The IMF analysis was performed at the Laboratory of Animal Feeding (LAMRA), UFU, based on the Manual of Analytical Procedures of the Brazilian Compendium of Animal Feeding (Anfar, 2005).

Loin samples were shredded, packed in aluminum dishes, weighed on a precision scale, and submitted to a pre-drying process, during which they were placed in a circulation heater for $72 \mathrm{~h}$ at $55^{\circ} \mathrm{C}$. Immediately thereafter, the samples were removed from the heater and weighed again. Samples were then individually subjected to grinding in a hammer-type mill with 5-mm sieves. Subsequently, $2 \mathrm{~g}$ of each sample was extracted by placing samples in a heater at a final temperature of $105^{\circ} \mathrm{C}$ for $6 \mathrm{~h}$, after which the amount of dry material (DM) and moisture $(\mathrm{M})$ were determined.

For the ether extract (EE) analysis, $3 \mathrm{~g}$ of each sample was packed in cartridges prepared with filter paper or a cartridge extractor. The cartridges were introduced into a previously dried flat-bottomed feeler, the solvent (petroleum ether) was added, the condenser settings were adjusted, and extraction was performed for $6 \mathrm{~h}$ at a condensation rate of 120-160 drops $/ \mathrm{min}$. The solvent was recovered, and the feeler was brought to a temperature of $105^{\circ} \mathrm{C}$ for $30 \mathrm{~min}$ to complete the drying process. Next, the solvent was cooled to room temperature in a desiccator and weighed.

$\mathrm{DM}$ was determined from the following equations: $\mathrm{HDS}=[\mathrm{DS}-(\mathrm{T} / \mathrm{S})] \mathrm{x} 100$ and $\mathrm{DM}$ $=($ HDS $\times$ ADS $) / 100$, where $\mathrm{S}=$ sample weight $(\mathrm{g}), \mathrm{T}=$ tare of the scale; $\mathrm{DS}=$ dry sample; ADS $=$ air-dried sample, and HDS $=$ heater-dried sample.

$\mathrm{M}$ was calculated by the following formula: $\mathrm{M}=100$ - DM, and the $\mathrm{EE} \%$, which corresponds to the IMF of the pre-drying sample, was calculated using the following expression: $\mathrm{EE} \%=[(\mathrm{A}-\mathrm{B}) / \mathrm{C}] \times 100$, where $\mathrm{A}=$ weight of the feeler or glass + residue $(\mathrm{g}), \mathrm{B}=$ weight of the feeler or cup $(\mathrm{g})$, and $\mathrm{C}=$ sample weight $(\mathrm{g})$.

The result of the above calculation was then used to calculate the \%DM using the following expression: \%DM $=(\mathrm{IMF} \times 100) / \mathrm{HDS}$.

Finally, to obtain the IMF content in fresh material (loin), which corresponds to the percentage of fresh material $(\% \mathrm{FM})$, the following calculation was performed: $\% \mathrm{FM}=\mathrm{IMF}$ (DM) x DM, where IMF (DM) is the IMF content of the dry material.

\section{Statistical analysis}

Data were submitted to analysis of variance (ANOVA) in a delineation entirely randomized model using the Tukey test for comparison between means at a 5\% level of significance. The SISVAR software (Ferreira, 2000) was used for all statistical analyses, and moisture was considered as a covariate of the characteristics studied. 


\section{RESULTS AND DISCUSSION}

Of the 144 carcasses examined, 61 (42.46\%) were from pigs with the normal halothane genotype (HalNN) and 83 (57.64\%) were from pigs heterozygous for the HAL gene (HalNn) (Table 1). These results differed from those obtained by Culau et al. (2002), who reported a prevalence of the HalNN genotype (61.59\%), and $33.77 \%$ were of the HalNn genotype, in 151 crossbred pigs derived from crosses of the Landrace, Large White, and Duroc breeds. McGloughlin (1980) found that although all pig breeds were capable of expressing the HAL gene, its incidence was higher in breeds with a high rate of lean meat, greater muscle content, and fast growth, such as Pietran and Poland China. Therefore, the higher occurrence of heterozygous animals in our study can be attributed to the use of the Pietran breed in the crosses. No carcasses with a recessive halothane genotype (Halnn) were detected in the present study. Both of the lines used in the present study (A and B) comprised HalNn and HalNN animals, and the effect of line was not significant in statistical analyses. Therefore, final analyses were performed without the line effect.

\begin{tabular}{lcc} 
Table 1. Frequencies of the halothane genotypes of the pigs studied (Uberlândia, MG, 2009). \\
\hline Genotype & Number of pigs & Percentage \\
\hline HalNN & 61 & 42.36 \\
HalNn & 83 & 57.64 \\
Halnn & 0 & 0 \\
Total & 144 & 100 \\
\hline
\end{tabular}

The average IMF content of all pigs analyzed was determined to be $2.14 \%$, which is considered to be low based on the criteria of Devol et al. (1988), who suggested that good-quality meat should have an IMF percentage from 2.5 to $3 \%$ for tenderness and $4 \%$ for palatability.

The medians, standard deviation, and coefficient of variation of IMF evaluated in the longissimus dorsi of swine carcasses are shown in Table 2 according to halothane genotype. The average IMF was $2.09 \%$ for homozygous dominant animals, and was $2.17 \%$ for heterozygous animals. Both of these values fall below the ideal IMF content (Devol et al., 1988); it is generally accepted that an increase in the IMF level has a positive influence on the sensorial quality of pork (Fernandez et al., 1999).

\begin{tabular}{|c|c|c|}
\hline IMF & HalNN & HalNn \\
\hline Mean & 2.098443 & 2.173241 \\
\hline Standard deviation & 0.46 & 0.61 \\
\hline CV\% & 22.22 & 28.49 \\
\hline
\end{tabular}

$\mathrm{IMF}=$ intramuscular fat.

The results of ANOVA revealed that none of the evaluated binary interactions were significantly different (Table 3), which was confirmed using the Tukey test (Table 4). There was no significant difference $(\mathrm{P}<0.05)$ in IMF content between the meat of homozygous dominant pigs (i.e., those free of the HAL gene) and the meat of heterozygous pigs. Guimarães 
et al. (2002) also found no significant differences in IMF content between pigs with the HalNN and HalNn genotypes, but did report differences in $\mathrm{pH}$ at $45 \mathrm{~min}$, and in drip and cooking loss parameters, which were not evaluated in the present study. These results suggest that although pigs carrying the HAL gene may exhibit a loss of meat quality, they have no disadvantages with respect to IMF deposition.

Table 3. ANOVA results for the intramuscular fat (IMF) variable and the halothane genotype (Uberlândia,
MG, 2009).
\begin{tabular}{lccccc} 
\\
Variation source & Degrees of freedom & Sum of squares & Mean square & F & P \\
\hline Hal & 1 & 0.196711 & 0.196711 & $0.628^{\text {ns }}$ & 0.4295 \\
Error & 142 & 44.500014 & 0.313380 & & \\
Total & 143 & 44.696726 & & & \\
\hline
\end{tabular}

${ }^{n s}$ Non-significant at $95 \%$ probability.

Table 4. Tukey test to compare mean intramuscular fat (IMF), at $95 \%$ significance, by halothane genotype (Uberlândia, MG, 2009).

\begin{tabular}{lcc}
\hline Treatments & IMF mean (\%) & Comparisons \\
\hline HalNN & 2.098443 & A \\
HalNn & 2.173241 & A \\
\hline
\end{tabular}

Means followed by the same letter do not differ statistically $(\mathrm{P}<0.05)$.

Studies conducted by Bridi et al. (2003) showed that the presence of the halothane allele did not affect meat tenderness, which confirmed results of Leach et al. (1996) and Channon et al. (2000). However, Kukoyi et al. (1981) and Tam et al. (1998) noted that meat derived from HalNn genotype pigs showed lower levels of IMF in the loin than did meat derived from homozygous dominant pigs, which is in contrast to the results obtained in the present study. Fisher et al. (2000) found that the meat from HalNn pigs was tougher than that from HalNN pigs, but these authors attributed this result to increased water loss during cooking rather than to differences in IMF content.

The lack of significant differences in the mean IMF content between the two genotypes analyzed indicates that the $\mathrm{n}$ allele, at least in heterozygotes, does not influence IMF deposition in swine carcasses, confirming the results of Van der Wal et al. (1993) and Bridi et al. (1998). Nevertheless, the correlation between this feature and the expression of other genes, for example, the FABP3 and FABP4 genes, as elucidated by Dekkers (2004), remains poorly characterized.

\section{ACKNOWLEDGMENTS}

We thank Fundação de Amparo à Pesquisa of Minas Gerais (FAPEMIG) for providing financial support for this study. We are also grateful to the Laboratory of Molecular Genetics, Federal University of Uberlândia (LAGEM/UFU) and to the Laboratory of Animal Feeding, Federal University of Uberlândia (LAMRA/UFU) for their cooperation and assistance with our analysis.

\section{REFERENCES}

Anfar (2005). Compêndio Brasileiro de Alimentação Animal-Métodos Analíticos. Sindirações, São Paulo.

Antunes RC (1997). O Efeito do Genótipo Hal sobre o Rendimento de Carne em Partes da Carcaça de Suínos Cruzados. 
Dissertação de Mestrado, Universidade Federal de Uberlândia, Uberlândia.

Bastos RG, Federizzi J, Deschamps JC and Cardellino RA (2001). Efeito do gene do estresse suíno sobre características de quantidade e qualidade de carcaça. R. Bras. Zootec. 30: 37-40.

Brazil (1952). Ministério da Agricultura, Pecuária e Abastecimento. Secretaria de Defesa Agropecuária-DAS. Departamento de Inspeção de Produtos de Origem Animal-DIPOA. Divisão de Normas Técnicas-DNT. Decreto Lei $\mathrm{n}^{\circ} 30.691$, de 29 de Março de 1952, Alterado pelos Decretos no 1.255, de 25 de Junho de 1962, $\mathrm{n}^{\circ} 1.812$, de 18 de Janeiro de 1996 e no 2.224 de 4 de Junho de 1997. Regulamento de Inspeção Industrial e Sanitária de Produtos de Origem Animal, Brasília.

Brenig B and Brem G (1992). Genomic organization and analysis of the 5' end of the porcine ryanodine receptor gene (ryr1). FEBS Lett. 298: 277-279.

Bridi AM, Müller L and Ribeiro JAR (1998). Indoor vs. Outdoor-Rearing of Pigs, Performance, Carcass and Meat Quality. Proceedings of the 44th International Congress of Meat Science and Technology, Barcelona, 521: 114-117.

Bridi AM, Rübensam JM, Nicolaiewsky S and Lopes RFF (2003). Efeito do genótipo halotano e de diferentes sistemas de produção na qualidade da carne suína. R. Bras. Zootec. 32: 1362-1370.

Channon HA, Payne AM and Warner RD (2000). Halothane genotype, pre-slaughter handling and stunning method all influence pork quality. Meat Sci. 56: 291-299.

Culau POV, López J, Rubensam JM and Lopes RFF (2002). Influência do gene halotano sobre a qualidade da carne suína. R. Bras. Zootec. 31: 954-961.

Dekkers JC (2004). Commercial application of marker- and gene-assisted selection in livestock: strategies and lessons. $J$. Anim. Sci. 82 (E-Supp 1): E313-E328.

Devol DL, McKeith FK, Bechtel PJ and Novakofski J (1988). Variation in composition and palatability traits and relationship between muscle characteristics and palatability traits and relationships between muscle characteristics and palatability in a random sample of pork carcasses. J. Anim. Sci. 66: 385-395.

Fávero JÁ and Bellaver C (2007). Produção de Carne de Suínos. Available at [http://www.cnpsa.embrapa.br/sgc/sgc_ arquivos/palestras_q7t2f5k.pdf]. Accessed July 19, 2010.

Fernandez X, Monin G, Talmant A, Mourot J, et al. (1999). Influence of intramuscular fat content on the quality of pig meat - 1. Composition of the lipid fraction and sensory characteristics of m. longissimus lumborum. Meat Sci. 53: 59-65.

Ferreira DF (2000). Análises Estatísticas por Meio do SISVAR (Sistema para Análise de Variância) para Windows Versão 4.0. Proceedings of the 45th Reunião Anual da Região Brasileira da Sociedade Internacional de Biometriap, UFScar, São Carlos, 255-258.

Fisher P, Mellett FD and Hoffman LC (2000). Halothane genotype and pork quality. 1. Carcass and meat quality characteristics of three halothane genotypes. Meat Sci. 54: 97-105.

Fujii J, Otsu K, Zorzato F, de Leon S, et al. (1991). Identification of a mutation in porcine ryanodine receptor associated with malignant hyperthermia. Science 253: 448-451.

Geers R, Bleus E, Van Schie T, Villé H, et al. (1994). Transport of pigs different with respect to the halothane gene: stress assessment. J. Anim. Sci. 72: 2552-2558.

Guimarães SEF, Band GO, Lopes PS, Schierholt AS, et al (2002). O Gene da Síndrome do Estresse Suíno e sua Relação com Características de Carcaça em Suínos F2 Resultantes de Cruzamentos Divergentes. Proceedings of the 4th Simpósio Nacional de Melhoramento Animal, Universidade Federal de Viçosa, Viçosa.

Kukoyi EA, Addis PB, McGrath CJ, Rempel WE, et al. (1981). Porcine stress syndrome and postmortem muscle characteristics of two purebreds and three specific terminal crosses. J. Anim. Sci. 52: 278-284.

Leach LM, Ellis M, Sutton DS, McKeith FK, et al. (1996). The growth performance, carcass characteristics, and meat quality of halothane carrier and negative pigs. J. Anim. Sci. 74: 934-943.

McGloughlin P (1980). Genetics Aspects of Pig Meat Quality. Pig News Inf. 1: 1.

Plastow GS (2000). Molecular Genetics in the Swine Industry. Proceedings of the 3rd Simpósio Nacional de Melhoramento Animal, Belo Horizonte, 21-30.

Roppa L (1999). Atualização sobre os Níveis de Colesterol, Gordura e Calorias da Carne Suína. Proceedings of the 36th Reunião Anual da Sociedade Brasileira de Zootecnia, Porto Alegre.

Rübensam JM (2000). Transformações Post Mortem e Qualidade da Carne Suína. Proceedings of the 1st Conferência Internacional Virtual Sobre Qualidade de Carne Suína, Concórdia, 89-99.

Saiki RK, Scharf S, Faloona F, Mullis KB, et al. (1985). Enzymatic amplification of beta-globin genomic sequences and restriction site analysis for diagnosis of sickle cell anemia. Science 230: 1350-1354.

Saiki RK, Gelfand DH, Stoffel S, Scharf SJ, et al. (1988). Primer-directed enzymatic amplification of DNA with a thermostable DNA polymerase. Science 239: 487-491.

Sambrook J, Fristch EF and Maniatis T (1989). Molecular Cloning: A Laboratory Manual. 2nd edn. Cold Spring Harbor Laboratory Press, New York. 
Sarcinelli MF, Venturini KF and Silva LC (2007). Características da Carne Suína. Boletim Técnico. Universidade Federal do Espírito Santo. Available at [http://www.agais.com/telomc/b00907_caracteristicas_carnesuina.pdf.]. Accessed July 19, 2010.

Sather AP, Jones SDM and Tong AKW (1991). Halothane genotype by interactions on pig meat quality. Can J. Anim. Sci. 71: 645-658.

Swatland HJ (1982). The challenge of improving meat quality. Can. J. Anim. Sci. 62: 15-24.

Tam LG, Berg EP, Gerrard DE, Sheiss EB, et al. (1998). Effect of halothane genotype on porcine meat quality and myoglobin autoxidation. Meat Sci. 49: 41-53.

Terra NN and Fries LLM (2001). A Qualidade da Carne Suína e sua Industrialização. Proceedings of the 1st Conferência Internacional Virtual Sobre Qualidade de Carne Suína, Concórdia, 147-151.

van der Wal PG, Mateman G, de Vries AW, Vonder GM, et al. (1993). 'Scharrel' (free range) pigs: Carcass composition, meat quality and taste-panel studies. Meat Sci. 34: 27-37.

Veerkamp JH, Van Moerkerk HT and Zimmerman AW (2000). Effect of fatty acid-binding proteins on intermembrane fatty acid transport studies on different types and mutant proteins. Eur. J. Biochem. 267: 5959-5966. 